\title{
HUBUNGAN KOPING RELIGIUS DENGAN TINGKAT DEPRESI PADA WARGA BINAAN WANITA DI LEMBAGA PEMASYARAKATAN
}

\author{
Akhmad Yanuar Fahmi ${ }^{1}$, Ria Sukmawati ${ }^{2}$ \\ ${ }^{1,2}$ Stikes Banyuwangi \\ Email: ahmad.yanuar@stikesbanyuwangi.ac.id
}

\begin{abstract}
ABSTRAK
Koping religius merupakan salah satu cara mengatasi depresi yang dialami seseorang dengan memperbaiki hubungan individu dengan Tuhan, Penelitian ini bertujuan untuk mengetahui hubungan koping religius dengan tingkat depresi. penelitian ini menggunakan Cross Sectional dengan tekhnik Purposive Sampling. sampel sebanyak 59 responden menggunakan intrumen DASS. Hasil perhitungan uji statistik Rank Spearmean didapatkan hasil Correlation Coefficient 0,447 dan Sig. (2tailed) $=0,000<0,05$ level (2-tailed) yang artinya Ho ditolak, ada hubungan koping religius dengan tingkat depresi yang dialami oleh warga binaan wanita di Lembaga Pemasyarakatan. Warga binaan wanita yang mengalami koping religius baik maka Narapidana tersebut tidak mengalami depresi atau normal dan sebaliknya.
\end{abstract}

Kata kunci: Koping Religius, Depresi, Lapas Wanita 


\title{
CORRELATION RELIGIOUS CLUTCH WITH DEPRESSION LEVELS IN WOMEN'S CITIZENS IN THE PRISON
}

\begin{abstract}
Religious coping is a way to overcome depression experienced by a person by improving the individual's relationship with God. This study aims to determine the relationship between religious coping and depression level. This study uses a cross sectional with purposive sampling technique. a sample of 59 respondents using the DASS instrument. The results of the calculation of the Rank Spearmean statistical test obtained the Correlation Coefficient results of 0.447 and Sig. (2-tailed) $=0.000<0.05$ level (2-tailed), which means that Ho is rejected, there is a relationship between religious coping and the level of depression experienced by female inmates in Corrections. Female assisted residents who experience good religious coping, the prisoner does not experience depression or normalcy and vice versa.
\end{abstract}

Keywords: Religious Coping, Depression, Women's prison

\section{PENDAHULUAN}

Lembaga Pemasyarakatan sejatinya merupakan tempat pembinaan bagi pelaku kejahatan yang telah dijatuhi putusan hukuman. sedangkan Narapidana atau warga binaan permasyarakatan adalah terpidana yang hilang kemerdekaan di lembaga pemasyarakatan, sedangkan terpidana adalah seseorang yang dipidana berdasarkan putusan pengadilan yang telah memperoleh kekuatan hukum tetap (Sukma Ayu, 2017).

Kondisi Lembaga

Pemasyarakatan dan perubahan hidup yang dialami narapidana menyebabkan tekanan yang terus menerus sehingga mereka tidak mampu mengubah sikap terhadap kondisi yang harus dihadapinya. Narapidana terpapar pada budaya baru, yang sangat berbeda dengan budaya atau kebiasaan yang dimilikinya, rentan menimbulkan efek psikologis negatif seperti menarik diri, depresi, pikiran untuk bunuh diri, dan peningkatan perilaku agresi (Kaloeti, Rahmandani, Kahija, \& Sakti, 2014). tidak dapat tidur, kehilangan selera makan, hasrat seksual dan minat serta kesenangan dalam aktivitas yang biasa dilakukan (Davison, Neale \& Kring, 2010). Narapidana yang tidak mampu memaknai atau mencapai makna dalam hidupnya, maka akan menimbulkan dampak psikologis yang negatif seperti depresi (Shollahuddin, 2015). Depresi merupakan kondisi emosional seseorang yang biasanya ditandai dengan kesedihan yang amat sangat, perasaan tidak berarti dan bersalah, menarik diri dari orang lain, tidak dapat tidur, kehilangan selera makan, hasrat seksual 
dan minat serta kesenangan dalam aktivitas yang biasa dilakukan (Davison, Neale \& Kring, 2010).

Sumber dari World Prison Population List, menyatakan bahwa lebih dari 10 juta orang menempati Lembaga Pemasyarakatan diseluruh dunia (Roy Walmsley, 2016). Diindonesia jumlah narapidana semakin meningkat, data yang terakhir didapatkan adalah sekitar 190 ribu narapidana berada di 477 Lembaga Pemasyarakatan (Dwitama, 2016 dalam Maharani , 2017). Prevalensi narapidana di Jawa Timur pada tahun 2017 sebanyak 15.530 jiwa, narapidana wanita sebanyak 692 jiwa dan laki laki sebanyak 14.838 jiwa. Pada tahun 2018 mengalami peningkatan yang signifikan sebanyak 18.446 jiwa, narapidana wanita sebanyak 847 jiwa. Data lebih spesifik menyatakan $23 \%$ dari narapidana negara di Amerika memiliki tanda dan gejala depresi. Penelitian pada narapidana di Nigeria tahun 2012 menunjukkan 48,7\% narapidana di Jos Maximum Security mengalami depresi. Sedangkan prevalensi depresi pada penduduk Indonesia usia $\geq 15$ tahun mencapai $6,1 \%$ dari jumlah penduduk di 33 Provinsi, di Jawa Timur angka kejadian depresi mencapai 5\% (RISKESDAS, 2018). Studi pendahuluan tingkat depresi di Lembaga Pemasyarakatan Klas IIB Banyuwangi didapatkan data dari 15 orang narapidana wanita yang normal sebanyak 3 orang, depresi ringan 3 orang, depresi sedang 6 orang, dan depresi berat 3 orang. Penyebab dari depresi tersebut yaitu karena rendahnya koping religius seseorang.
Mosher dan Handal menyatakan bahwa seseorang yang mempunyai religiusitas yang rendah maka akan menyebabkan tingginya tingkat depresi seseorang (Muhana, 2012 dalam Erlina, 2015). Sedangkan Koping religius merupakan salah satu cara mengatasi depresi yang dialami seseorang dengan memperbaiki hubungan individu dengan Tuhan (Anggraini, 2015)

Narapidana wanita lebih rentan mengalami permasalahan psikologis karena mereka tidak dapat menerima keadaannya, status baru yang disandang sebagai narapidana yang masih mempunyai stigma negatif di masyarakat membuat seorang narapidana merasa depresi (Fauziyah Ardilla dan Ike Hediana 2013). Penyebab dari depresi tersebut yaitu karena rendahnya koping religius seseorang, Pergament mengatakan koping religius adalah upaya memahami dan mengatasi sumber-sumber depresi dalam hidup dengan melakukan berbagai cara untuk mempererat hubungan individu dengan Tuhan (Anggraini, 2015). Mosher dan Handal menyatakan bahwa seseorang yang mempunyai religiusitas yang rendah maka akan menyebabkan tingginya tingkat depresi seseorang (Muhana, 2012 dalam Erlina, 2015). Religiusitas telah di kaitkan dengan kesehatan mental dan kesejahteraan yang lebih baik. Khususnya, religiusitas yang tinggi memprediksi rendahnya depresi, penggunaan zat adiktif, perilaku anti sosial, dan bunuh diri. Keyakinan agama telah terbukti memiliki banyak manfaat, dengan adanya beberapa penelitian yang menunjukkan hubungan 
positif antara agama dan kesehatan terkait dengan adanya hubungan agama dengan kesehatan mental (Plante \& Sharma,2001 dalam Andi, 2016)

Seorang

narapidana

membutuhkan cara - cara untuk

meningkatkan koping religius, diantaranya yaitu dengan meningkatkan aspek positif koping religius meliputi benevolent religious reappraisal, collaborative religious coping, seeking spiritual support, religious purification, spiritual connection, seeking support from clergy or members, religious helping, dan religious forgiving. Pergament menyatakan dalam penelitian yang dilakukan Utami (2012) tentang Religiusitas, Koping Religius dan Kesejahteraan Subjektif, bahwa religi dapat menjadi bagian sentral dari konstruksi koping (Utami, 2012). Dengan adanya konstribusi positif yang diberikan agama dalam koping depresi pada masing - masing individu, menunjukkan bahwa agama bisa berarti lebih dalam kehidupan manusia, enelitian ini bertujuan untuk mengetahui hubungan koping religius dengan tingkat depresi. Pentingnya penelitian ini adalah belum ada eksplorasi koping religius pada penelitian sebelumnya.

\section{METODE PENELITIAN}

Penelitian ini menggunakan penelitian kuantitatif non eksperimen melalui pendekatan Cross Sectional. Tekhnik sampling yang digunakan yaitu Purposive Sampling. Pengumpulan data pada penelitian ini menggunakan lembar kuesioner DASS. Jumlah populasi pada penelitian ini sebanyak 69 responden, dengan jumlah sampel sebanyak 59 responden

\section{HASIL DAN PEMBAHASAN}

Penelitian ini dilaksanakan Warga Binaan Wanita di Lembaga

Pemasyarakatan Klas IIB Banyuwangi mulai dari bulan November sampai

Desember 2018. Jumlah subjek yang diteliti ada 59 responden

Table 1. Distribusi frekuensi responden berdasarkan tingkat koping religius dan tingkat depresi

\begin{tabular}{lcc}
\hline \multicolumn{1}{c}{ Variabel } & N & \% \\
\hline Koping Religius & 41 & 69 \\
Baik & 18 & 31 \\
Sedang & 0 & 0 \\
Buruk & & \\
Depresi & 34 & 58 \\
Normal & 19 & 32 \\
Ringan & 6 & 10 \\
Sedang & 0 & 0 \\
Berat & & \\
\hline
\end{tabular}

Table 2. Hubungan koping religius dengan tingkat depresi pada Warga binaan wanita Lembaga Pemasyarakatan 


\begin{tabular}{llccccccccc}
\hline \multirow{2}{*}{ Variabel } & \multirow{2}{*}{ Kategori } & \multicolumn{10}{c}{ Tingkat Depresi } \\
\cline { 3 - 12 } & & Normal & \multicolumn{1}{c}{ Ringan } & Sedang & Berat & P \\
\hline & & $\mathrm{N}$ & $\%$ & $\mathrm{~N}$ & $\%$ & $\mathrm{~N}$ & $\%$ & $\mathrm{~N}$ & $\%$ & \\
\hline Koping & Baik & 29 & 69 & 11 & 26 & 1 & 5 & 0 & 0 & \\
religius & Sedang & 5 & 28 & 8 & 44 & 5 & 28 & 0 & 0 & 0,447 \\
& Buruk & 0 & 0 & 0 & 0 & 0 & 0 & 0 & 0 & \\
\hline
\end{tabular}

Tabel 2 diatas dapat diketahui bahwa 41 responden yang mengalami koping religius baik, sebagian besar responden tidak mengalami depresi atau normal selama berada di Lapas yaitu sebanyak 29 responden (69\%). Dari 18 responden yang mengalami koping religius sedang, hampir setengahnya responden mengalami depresi ringan sebanyak 8 responden (44\%).

Hasil penelitian menunjukan Setelah dilakukan uji analisa dengan uji Rank Spearmen SPSS versi 22 didapatkan hasil Correlation Coefficient 0,447 dan Sig. (2-tailed) $=0,000<0,05$ level (2-tailed) yang artinya Ho ditolak Ha diterima yang mempunyai arti ada hubungan koping religius dengan tingkat depresi pada warga binaan wanita di Lembaga Pemasyarakatan Klas IIB Banyuwangi pada Tahun 2019. Nilai korelasi Rank Spearman adalah 0,447 berada pada posisi $0,30-$ 0,49 moderat atau cukup yang berarti koping religius dengan tingkat depresi pada warga binaan wanita di Lembaga Pemasyarakatan Klas IIB Banyuwangi moderat atau cukup.

Perubahan kondisi dan pola hidup yang ada di Lembaga pemasyrakatan menyebabkan tekanan yang terus menerus yang dialami oleh narapidana menyebabkan dirinya tidak mampu beradaptasi dan akan menimbulkan efek negatif terhadap psikologis narapidana seperti menarik diri, depresi, pikiran untuk bunuh diri, dan peningkatan perilaku agresi (Kaloeti et al, 2014). Penelitian yang lain memperoleh hasil bahwa religi sangat berpengaruh terhadap koping (Utami, 2012)

Ellison dan Taylor (1996) dalam Tenri, 2016 mengemukakan bahwa koping religius menjadi cara yang paling berpengaruh dalam kelompok sosial. Doa, pasrah dan ibadah yang lain dapat dengan signifikan dalam menangani depresi, masalah kesehatan, dan kematian. Koping religius baik terbukti memberikan dampak baik terhadapa Narapidana. Didapat dari hasil penelitian pada warga binaan wanita yang mengalami koping religius baik dan tidak mengalami depresi atau normal 29 responden (69\%) dikarenakan koping yang dilakukan narapidana dalam mengatasi masalahnya yaitu dengan cara mempererat hubungannya dengan Tuhan, seperti meminta ampunan terhadapan tindakan yang dilakukan sebelumnya yang menyebabkan narapidana masuk kedalam Lembaga Pemasyarakatan dan percaya bahwa Tuhan akan membantu terhadap musibah yang sedang ditimpanya saat ini, sehingga perasaan yang dialami narapidana sangat tenang, nyaman, dan merasa aman. Perasaan percaya diri secara bertahap kembali muncul 
sehingga dapat mempengaruhi pikiran dan tindakan menjadi positif, dan yang terpenting adalah agama memiliki kontribusi yang besar terhadap hidup mereka.

Narapidana yang mengalami koping religius baik dengan depresi ringan sebanyak 11 responden (26\%), karena sebagian besar responden yang telah tinggal di Lembaga Pemasyarakatan kurang dari 1 tahun sebanyak 34 responden (58\%) yang artinya masih dalam tahap penyesuaian dengan keadaan lapas karena setiap pagi hingga sore hari narapidana menghabiskan waktunya di mushollah sembari melakukan ibadah seperti beristigfar sholat 5 waktu dan ketika malam hari narapidana kembali kedalam sel yang fasilitasnya kurang memadahi sehingga menimbulkan ketidaknyaman. Sedangkan narapidana yang mengalami koping religius baik dan mengalami depresi sedang sebanyak 1 responden (5\%) dikarenakan tidak dapat tidur nyenyak selama berada di Lapas karena menyesali perbuatan yang telah dilakukan, merasa kecewa terhadap diri sendiri, dan permasalahan ini adalah pelajaran berharga yang Tuhan berikan, sehingga narapidana memohon ampunan dan perlindungan kepada Tuhan.

Narapidana mengalami Koping religius sedang dan tidak mengalami depresi 5 responden (28\%) dikarenakan cara menggunakan koping religius masih kurang sehingga merasa bahwa masalah yang sedang dialami merupakan hukuman dari Tuhan. Pada saat menghadapi masalah narapidana lebih senang menghibur diri dengan bersenang-senang seperti menyayi karena di Lembaga Pemasyarakatan juga menyediakan panggung hiburan. Narapidana yang mengalami koping religius sedang depresi ringan sejumlah 8 responden (44\%) disebabkan responden mengalami sedih dan merasa bersalah sepanjang waktu karena keseluruhan narapidana berjenis kelamin wanita, dimana wanita sangat rentan sekali mengalami depresi karena lemahnya pertahan diri yaitu faktor yang ada di dalam diri untuk mengontrol dan mempertahankan diri terhadap lingkungan penjara. Narapidana yang mengalami koping religius sedang dengan depresi sedang sebanyak 5 responden (28\%) dikarenakan sebagian besar responden berstatus menikah yang berjumlah 34 responden $(58 \%)$. Narapidana yang sudah menikah tentunya mereka memiliki keluarga yang harus di tinggalkan, sehingga narapidana merasa berat dengan keadaan tersebut.

Pentingnya koping religius bagi narapidana yaitu dapat membangun kelekatan dengan orang lain, kontrol diri, mengurangi depresi, sebagai jalan mencari dan menemukan cara-cara untuk lebih dekat dengan tuhan (Ibid., hlm: 142). Terbukti bahwa ketika narapidana mempunyai spiritual atau religiusitas yang tinggi terhadap Tuhan, mak akan terlihat senantiasa bersikap lebih menerima kepada-Nya ketika narapidana menggunakan koping religius dalam kesehariannya maka narapidana mempunyai sikap optimis. 
sehingga dapat mengurangi tingkat depresi dalam kehidupan (Angganantyo, 2017). Religiusitas telah di kaitkan dengan jiwa yang baik. Ada keterkaitan antara religiusitas yang tinggi dengan rendahnya depresi, minuman keras, dan bunuh diri. Pemahaman yang tinggi terhadap agama mempunyai banyak manfaat, dengan adanya beberapa penelitian yang menunjukkan ada keterkaitan positif antara keyakinan terhadap agama dan peningkatan kesehatan (Plante \& Sharma,2001 dalam Andi, 2016).

\section{KESIMPULAN}

Sebagian besar warga binaan wanita di Lembaga Pemasyarakatan Klas IIB Banyuwangi Tahun 2019 mengalami koping religius baik. Terdapat 1 responden (5\%) mengalami depresi dan tidak dapat tidur nyenyak selama berada di Lapas karena menyesali perbuatan yang telah dilakukan, merasa kecewa terhadap diri sendiri, dan permasalahan ini adalah pelajaran berharga yang Tuhan berikan, sehingga narapidana memohon ampunan dan perlindungan kepada Tuhan. Pentingnya koping religius bagi narapidana yaitu dapat membangun kelekatan dengan orang lain, kontrol diri, mengurangi depresi, sebagai jalan mencari dan menemukan cara-cara untuk lebih dekat dengan tuhan. Terbukti bahwa ketika narapidana mempunyai spiritual atau religiusitas yang tinggi terhadap Tuhan, mak akan terlihat senantiasa bersikap lebih menerima kepada-Nya ketika narapidana menggunakan koping religius dalam kesehariannya maka narapidana mempunyai sikap optimis. sehingga dapat mengurangi tingkat depresi dalam kehidupan. Religiusitas telah di kaitkan dengan jiwa yang baik. Ada keterkaitan antara religiusitas yang tinggi dengan rendahnya depresi, minuman keras, dan bunuh diri. Pemahaman yang tinggi terhadap agama mempunyai banyak manfaat, dengan adanya beberapa penelitian yang menunjukkan ada keterkaitan positif antara keyakinan terhadap agama dan peningkatan kesehatan (Plante \& Sharma,2001 dalam Andi, 2016). Dalam religiusitas banyak intervensi yang digunakan dalam mengurangi gangguan psikososial, diantaranya adalah mindfulness spiritual islam (Yanuar, Dwidiyanti, \& W, 2018), dan beberapa intervensi seperti ruqyah syariyah dapat mengurang tingkat, stress, ansietas, dan depresi.

\section{UCAPAN TERIMAKASIH}

Pada kesempatan ini, peneliti ingin mengucapkan terima kasih kepada berbagai pihak yang telah membantu terwujudnya penelitian ini : Ketua Lembaga Penelitian dan Pengabdian Sekolah Tinggi Ilmu Kesehatan

\section{DAFTAR PUSTAKA}

Angganantyo, W. (2014). Coping Religius Pada Karyawan Muslim Ditinjau Dari Tipe Kepribadian. Jurnal Ilmiah Psikologi Terapan, 2(1), 50-61. https://doi.org/10.22219/JIPT.V2I1. 1769

Dwidiyanti, M., Fahmi, A. Yanuar., Ningsih, H. E. W., Wiguna, R. I., \& Munif (2019, hlm 78). Seni 
Mindfulness Spiritual Islam (1st ed.). Semarang: UNDIP Predss

Dwitama, 2016 dalam Maharani . (2017). Hubungan Antara Dukungan Sosial Dengan Depresi Pada Narapidana Di Rumah Tahanan Negara Kelas II Purwodadi, 2.

Ellison \& Taylor, E.S. (1996). Psikologi Sosial. Jakarta: Kencana

Erlina. (2015). Strategi Regulasi Emosi Dan Perilaku Koping Religius Narapidana Wanita Dalam Masa Pembinaan, 48.

Kaloeti, D. V. S., Rahmandani, A., Kahija, Y. F. La, \& Sakti, H. (2014). Gambaran Depresi Warga Binaan Pemasyarakatan $X$ Depression Among Inmates Of $X$ Correctional Facility In Semarang, 115-119.

Liu, Gao, Xia, dan Zhao. (2009). Investigation of the sitespecific accumulation of catechin in the tea plant (Camellia sinensis (L.) O. Kuntze) via Vanillin- $\mathrm{HCl}$ Staining. J. Agric. Food Chem., 57, 10371-10376.

Miller, A. J. (1999). Gender and Forgiveness: A meta-analityic review and research agenda. Journal of Social And Clinical Psycology. 27 (843-876)

Muhana, S.U. (2012). Religiusitas dan Psycological Well-Being Pada
Korban Gempa. Jurnal Psikologi. 34, 2, 164 - 176.

Pargament, K.I., Smith, B.W., Koenig, H.G., \& Perez, L. (1998). Patterns of positive and negative religious coping with major life stressors. Journal for the Scientific Study of Religion, 37, 710-724.

Pargament, Kenneth., Feuille, Margaret., \& Burdzy, Donna. (2011). The Brief RCOPE: Current Psychometric Status Of A short Measure Of Religious Coping. Religions, 2,51-76; doi:10.3390/rel2010051

RISKESDAS. (2018). Hasil Riset Kesehatan Dasar. Dari https://www.kemkes.go.id /resources/download/infoterkini/hasil-riskesdas-2018.pdf

Roy Walmsley. (2016). World Prison Population List. Institute For Criminal Policy Research, eleventh edition

Suharsono, Y. Andi, S. (2016). Hubungan Persepsi terhadap Kesehatan dengan Kesadaran Mindfulness Menyetorkan Sampah Anggota Klinik Asuransi Sampah di Indonesia Medika. Jurnal Ilmiah Psikologi Terapan Universitas Muhammadiyah Malang, Vol.4 No.1

DOI: https://doi.org/10.22219/jipt.v4i1.2 876

Tenri, A. N. K. (2016). Pengaruh Subjective Well-Being dan Religious Coping Terhadap Stres pada Anggota Bintara 
Polisi Di Polda Banten, 27-32

Dari

http://repository.uinjkt.ac.id/ds pace/handle/123456789/38741

Utami,M.S. (2012). Religiusitas, Koping Religius dan Kesejahteraan Subjektif. Journal of Social and Clinical Psycology. 27 (843-876), Vol: 39(1), 46-66.
Yanuar,A.,Dwidiyanti,M.,\&W,D,Y.

(2018). Effectiveness of Mindfulness on Decreasing Stress in Health Professional Students : A Systematic Review. Holistic Nursing and Health Since, 1(1), 1-11. Dari : https://doi.org/10.14710/hnhs.1 .1.2018.1-11 